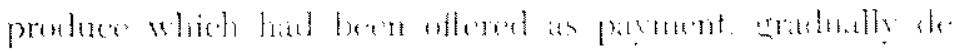
creased

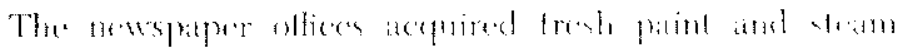

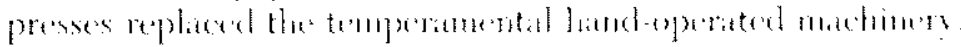

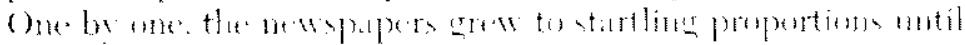

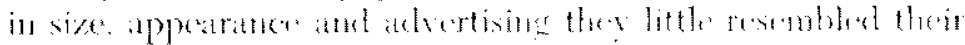
hamble prodecessors.

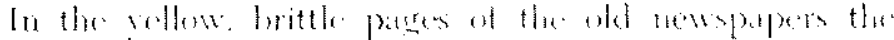

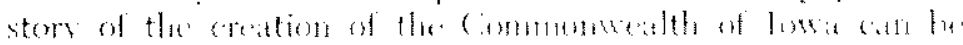

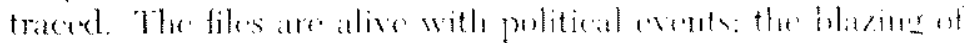

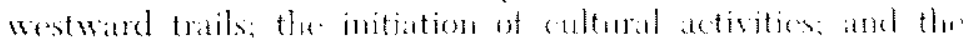

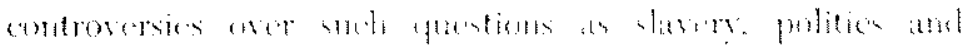

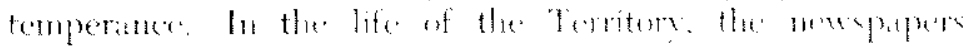

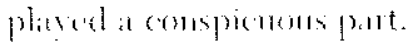

\title{
NEWSPAPER DIVISION ACTIVE IN RECORDING IOWA'S HISTORY
}

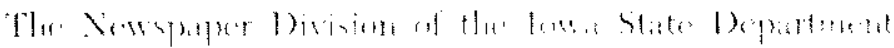

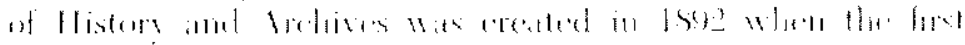

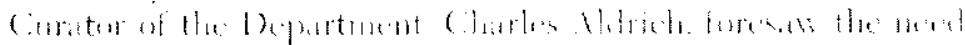

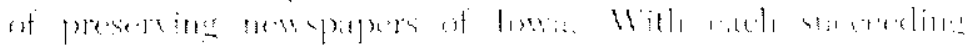

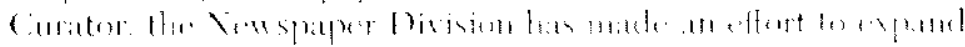

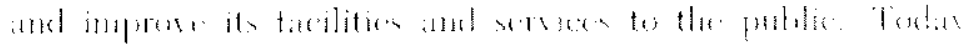

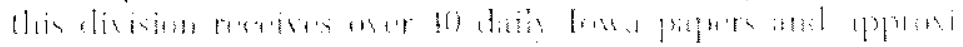

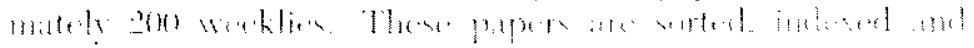

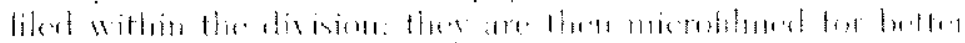

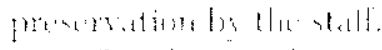

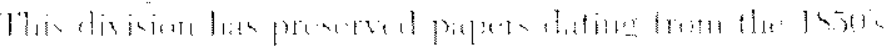

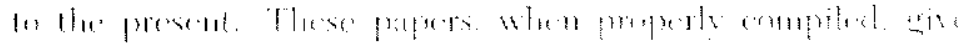

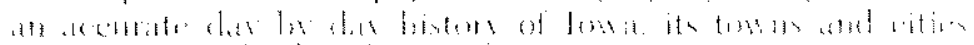

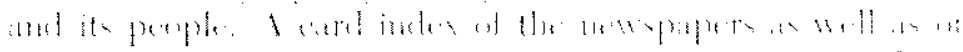

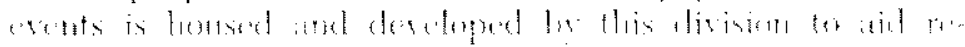

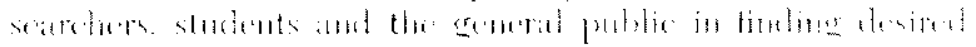
infortitfions.

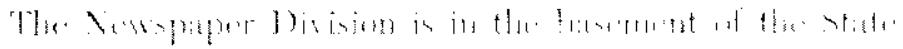

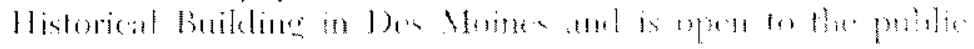

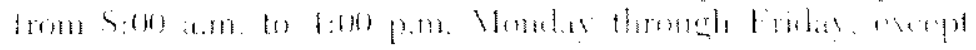
lulitils 
Copyright of Annals of Iowa is the property of State of Iowa, by \& through the State Historical Society of Iowa and its content may not be copied or emailed to multiple sites or posted to a listserv without the copyright holder's express written permission. However, users may print, download, or email articles for individual use. 